\title{
Rapid Stability Indicating HPLC Method for the Analysis of Leflunomide and Its Related Impurities in Bulk Drug and Formulations
}

\author{
Bulk İlaç ve Formülasyonlarda Leflunomid ve Illgili Safsızlıklarının Analizi \\ için Hızlı Stabilite Göstergeli YBSK Yöntemini
}

\author{
(D) Useni Reddy MALLU, (D) Venkateswara Rao ANNA, (D) Bikshal Babu KASIMALA* \\ Koneru Lakshmaiah Education Foundation, Department of Chemistry, Guntur, Andhra Pradesh, India
}

\begin{abstract}
Objectives: Leflunomide (LFNM) is a drug that belongs to isoxazole derivatives and has immunosuppressive and anti-inflammatory activities. A literature search confirms that there is no method reported for the simultaneous estimation of LFNM and its related impurities $A$ and $B$ in pharmaceutical dosage forms or in bulk drug. Hence the present work aimed to develop a simple stability indicating RP-HPLC method for the separation and quantification of LFNM and its impurities A and B.

Materials and Methods: Systematic trials of method conditions like mobile phase ratio, $\mathrm{pH}$, flow rate, stationary phase, and detector wavelength were performed for the simultaneous analysis of LFNM and its related impurities A and B. The developed method was validated as per the ICH guidelines including forced degradation studies in different stress conditions.

Results: Optimized separation was achieved on a Thermo Scientific Hypersil ODS C18 column (250 mm×4.6 mm; $5 \mu \mathrm{m}$ id) using mobile phase composition of acetonitrile, methanol, and $0.1 \mathrm{M}$ sodium perchlorate in the ratio of 40:30:30 (v/v), pH 4.6, at a flow rate of $1.0 \mathrm{~mL} / \mathrm{min}$ in isocratic elution. UV detection was carried out at a wavelength of $246 \mathrm{~nm}$. Well-resolved peaks were observed with high numbers of theoretical plates, lower tailing factor, and reproducible relative retention time and response factor. The method was validated and all the validation parameters were found to be within the acceptance limits. Stability tests were done through exposure of the analyte solution to five different stress conditions, i.e. $1 \mathrm{~N} \mathrm{HCl}$, $1 \mathrm{~N} \mathrm{NaOH}, 3 \% \mathrm{H}_{2} \mathrm{O}_{2}$, thermal degradation of powder, and exposure to UV radiation. The method can successfully separate the degradation products along with both the impurities studied. The \% degradation was also found to be less.

Conclusion: The method developed for LFNM is simple and precise and can be applied for the separation and quantification of LFNM and its related impurities in bulk drug and pharmaceutical formulations.
\end{abstract}

Key words: Leflunomide, impurity A, impurity B, stress degradation, HPLC

ÖZ

Amaç: Leflunomid (LFNM), izoksazol türevine ait ve immüne süpresif ve antienflamatuvar aktiviteye sahip bir ilaçtır. Literatür taraması, farmasötik dozaj formlarında ve bulk ilaçlarda LFNM ve ilgili safsızık A ve B'nin değerlendirilmesi için rapor edilen bir yöntemin olmadığını doğrulamaktadır. Bu nedenle bu çalışma, LFNM'nin ve A ve B safsızlıklarının ayrıştırılması ve miktarının belirlenmesi için hızlı stabilite göstergeli RP-YBSK yöntemini geliștirmeyi amaçlamıştır.

Gereç ve Yöntemler: LFNM ve ilgili safsızlık A ve B'nin eş zamanlı analizi için mobil faz oranı, pH, akış hızı, stasyoner faz ve detector dalga boyu gibi metod koşullarının sistematik testleri gerçekleştirilmiştir. Geliştirilen yöntem farklı stress koşullarında zoraki bozunma çalışmalarını içeren ICH yönergelerine göre valide edilmiştir.

Bulgular: Optimal ayrıştırma, Thermo Scientific Hypersil ODS C18 kolonu (250 mm×4,6 mm; 5 m id) üzerinde, 40:30:30 (h/h) oranında asetonitril, methanol ve 0,1 M sodium perklorat bileşiminden oluşan mobil faz kullanılarak elde edilmiştir; izokratik elüsyonda 1,0 mL/dak akış hızında pH 4,6 idi. UV saptaması $246 \mathrm{~nm}$ dalga boyunda gerçekleştirilmiştir. İyi-kararlı pikler, çok sayıda teorik plaka, daha az kuyruklama faktörü ve tekrarlanabilir göreceli retansiyon süresi ve tepki faktörü ile elde edilmiștir. Yöntem valide edilmiștir ve tüm validasyon parametreleri kabul limitinde bulunmuştur. Stabilite testleri, analit çözeltisinin beş farklı stress koşuluna, yani $1 \mathrm{~N} \mathrm{HCl}, 1 \mathrm{~N} \mathrm{NaOH}, \% 3 \mathrm{H}_{2} \mathrm{O}_{2}$, tozun termal degradasyonuna ve UV radyasyonuna

*Correspondence: E-mail: bikshalbabu@gmail.com, Phone: +9533163683 ORCID: orcid.org/0000-0002-0608-0473

Received: 11.06.2018, Accepted: 31.08.2018

-Turk J Pharm Sci, Published by Galenos Publishing House. 
maruz kalması yoluyla gerçekleştirilmiştir. Yöntem, bozunma ürünlerini çalışılan safsızlıklarla birlikte başarılı bir şekilde ayırabilmiştir. Yüzde degradasyon da daha az bulunmuștur.

Sonuç: LFNM'nin ayrılması ve miktar tayini için geliştirilen yöntem basit ve kesindir ve bulk ilaç ve farmasötik formülasyonlarda LFNM'nin ve ilgili safsızlıklarının ayrıştırılması ve analizi için uygulanabilir.

Anahtar kelimeler: Leflunomide, safsızlık A, safsızlık B, stress bozulması, YBSK

\section{INTRODUCTION}

Leflunomide (LFNM) is an isoxazole derivative having both immunosuppressive and anti-inflammatory activities.' LFNM acts as a dihydroorotate dehydrogenase inhibitor used for the treatment of rheumatoid arthritis. ${ }^{2,3}$ It is also used to treat psoriasis, psoriatic arthropathy, ${ }^{4}$ and other inflammatory conditions like bullous pemphigoid, Felty syndrome, Sjögren syndrome, Wegener granulomatosis, and vasculitis. ${ }^{5}$ The most common side effects associated with LFNM are nausea, vomiting, diarrhea, abdominal pain, alopecia, and hypertension. ${ }^{6}$ The literature reveals that methods are reported for the estimation of LFNM in pharmaceutical formulations using high performance liquid chromatography (HPLC), ${ }^{7-14}$ UPLC, ${ }^{15}$ and spectrophotometer. ${ }^{16,17}$ Only one HPLC method was reported for the simultaneous estimation of LFNM with other NSAIDs. ${ }^{18}$ Bioanalytical methods are reported for estimation of LFNM in biological samples using HPLC, 19 HPTLC, ${ }^{20}$ and liquid chromatography. ${ }^{21}$ The other methods reported were determination of the active metabolite of LFNM in biological samples using HPLC. ${ }^{22-24}$ No methods are reported for the estimation of LFLM and its USP related impurities in pharmaceutical formulations. Hence in the present study we attempted to develop a simple method for the estimation of LFLM (5-methyl-N-[4-(trifluoromethyl) phenyl]-isoxazole-4carboxamide) and its related impurities $A(\alpha, \alpha, \alpha$-trifluoro-ptoluidine, 4-(trifluoromethyl)aniline, 4-aminobenzotrifluoride) and B (2-cyano-3-hydroxy-N-(4-trifluoromethylphenyl) crotonamide) in pharmaceutical formulations. The molecular structure of LFNM and its related compounds in the study are given in Figure 1.

\section{MATERIALS AND METHODS}

\section{Instrumentation}

The separation and estimation of LFNM with impurities $A$ and $B$ were conducted on a PEAK HPLC (India) system. The<smiles>Cc1oncc1C(=O)Nc1ccc(C(F)(F)F)cc1</smiles>

LFNM<smiles>Nc1ccc(C(F)(F)F)cc1</smiles>

Impurity $\underline{\underline{\mathrm{A}}}$ mobile phase was pumped into the column using an LC-P7000 isocratic pump. A 20- $\mu \mathrm{L}$ fixed volume sample was injected for the analysis using a Rheodyne injector (model 7725) with a fixed $20-\mu \mathrm{L}$ loop. A variable wavelength programmable (Waters 486) ultraviolet (UV)-visible detector was used for detecting the compounds. The detector response signals were monitored and integrated using Young Lin Autochro-3000 software (Korea). Samples were injected using a Hamilton (USA) manual HPLC syringe. A double beam UV-visible spectrophotometer (Teccomp UV-2301, India) was used for the spectral analysis. A Denver electronic analytical balance (SI-234) was used for weighing the standards and samples. $\mathrm{pH}$ of the mobile phase was adjusted using a Systronics (India) digital $\mathrm{pH}$ meter ( $\mathrm{Sr}$ No: S 1326).

\section{Chemicals and reagents}

The active pharmaceutical ingredient LFNM with $99.20 \%$ purity and its two impurities $A$ and $B$ were obtained as gift samples from Torrent Pharmaceuticals Limited, Secundrabad, Telangana, India. The marketed formulation of LFNM (Lefno ${ }^{\odot}-10 \mathrm{mg}$ ) was purchased in a local pharmacy. Laboratory reagent grade sodium perchlorate monohydrate $\left(\mathrm{NaClO}_{4} \cdot \mathrm{H}_{2} \mathrm{O}\right)$ and perchloric acid $\left(\mathrm{HClO}_{4}\right)$ were purchased from SD Fine Chem. Limited, Mumbai. HPLC grade methanol, acetonitrile, and water were purchased from Merck Chemicals, Mumbai, and 0.2- $\mu$ m nylon membrane filter papers were used for filtration of samples and mobile phase and were purchased from Millipore (India).

\section{Preparation of solutions}

\section{Sodium perchlorate solution $(0.1 \mathrm{M})$}

First $14.046 \mathrm{~g}$ of $\mathrm{NaClO}_{4} \cdot \mathrm{H}_{2} \mathrm{O}$ was weighed accurately and dissolved in $500 \mathrm{~mL}$ of water (HPLC grade). Then it was sonicated for 2-5 min to dissolve the compound completely in the water. The final volume was made up to the mark in a 1000$\mathrm{mL}$ volumetric flask using water. The solution was filtered through a $0.45-\mu m$ nylon membrane filter paper.<smiles></smiles>

Impurity B

Figure 1. Molecular structure of LFNM and its related compounds in the study LFNM: Leflunomide 
Perchloric acid solution $(0.1 \mathrm{M})$

First $70 \%$ perchloric acid having molarity $11.6 \mathrm{M}$ was used for the preparation of $0.1 \mathrm{M}$ solution. Then $8.6 \mathrm{~mL}$ of $\mathrm{HClO}_{4}$ was pipetted and was further made up to $1000 \mathrm{~mL}$ using water. The solution was sonicated and filtered through $0.45-\mu \mathrm{m}$ nylon membrane filter paper.

\section{Standard drug and impurity solutions}

First $100 \mathrm{mg}$ of standard drug LFNM was weighed accurately and then put in a $100-\mathrm{mL}$ volumetric flask. The drug was dissolved in approximately $75 \mathrm{~mL}$ of methanol. Then the final volume was made up to $100 \mathrm{~mL}$ with methanol. LFNM standard stock solution of $1000 \mu \mathrm{g} / \mathrm{mL}$ was obtained and $1 \mathrm{~mL}$ of it was accurately pipetted into a $100-\mathrm{mL}$ volumetric flask and the final volume was made up to the mark to get LFNM working standard solution of $10 \mu \mathrm{g} / \mathrm{mL}$.

The procedure explained for the preparation of LFNM standard solution was followed for the preparation of $10 \mu \mathrm{g} / \mathrm{mL} \operatorname{Imp} A$ and Imp B separately. Ten milliliters of LFNM, Imp A, and Imp B were mixed separately and the mixture solution was used for method development.

\section{Formulation solution}

Ten tablets of LFNM (Lefno ${ }^{\odot}-10 \mathrm{mg}$ ) were powdered using a sterile mortar and pestle to get a fine powder. From the tablet powder an amount of drug equivalent to $10 \mathrm{mg}$ of LFNM was weighed accurately and was dissolved in $10 \mathrm{~mL}$ of methanol. The solution was kept in an orbital shaker for $15 \mathrm{~min}$ to dissolve the drug completely in solvent. Then it was filtered through 0.45$\mu \mathrm{m}$ nylon membrane filter paper. Sample solution containing $1000 \mu \mathrm{g} / \mathrm{mL}$ LFNM was obtained. The sample stock solution was further diluted to get a working sample solution having a LFNM concentration of $250 \mu \mathrm{g} / \mathrm{mL}$. This solution was used for the identification and estimation of LFNM and its impurities $A$ and $\mathrm{B}$ in pharmaceutical formulations.

\section{Method development}

The standard drug solution containing $10 \mu \mathrm{g} / \mathrm{mL}$ concentrations of both impurities and LFNM was initially used for method development studies. The wavelength of the detector was maintained based on the iso-absorption wavelength obtained by UV spectrophotometer for LFNM and impurities A and B. System suitability, resolution, response factor (RF), and peak symmetry are the key factors that are taken into consideration for optimization of the mobile phase. The mobile phase was confirmed by changes in different solvent ratios, strength of organic modifiers, and $\mathrm{pH}$. Separation was performed on different column configurations and manufactures. The flow rate of the mobile phase also changed in order to get better resolution. The conditions that give the best resolution, response, and peak symmetry were considered suitable conditions and these conditions were further validated for the applicability of the method for the estimation of LFNM and its related impurities $A$ and $B$ in pharmaceutical formulations.

\section{Method validation}

The method was validated as per ICH guidelines. ${ }^{25}$

\section{System suitability}

System suitability tests were carried out on a freshly prepared standard solution at three concentrations (10, 20, and $30 \mu \mathrm{g} /$ $\mathrm{mL}$ ) of the LFNM, Imp A, and Imp B to scrutinize the various optimized parameters such as retention time, relative RF (RRF), resolution, tailing factor, and USP plate count.

\section{Linearity and range}

Standard calibration curves were prepared with six calibrators over a concentration range of 0.5-3.0 $\mu \mathrm{g} / \mathrm{mL}$ for LFNM, Imp A, and Imp B. The solutions were analyzed in triplicate in the optimized conditions. The data of peak area vs. drug concentration were analyzed using linear least square regression.

\section{Precision}

Precision was determined using six standard solutions containing $2 \mu \mathrm{g} / \mathrm{mL}$ LFNM, Imp A, and Imp B that were prepared and analyzed in the optimized method conditions. For intraday precision the solutions were prepared and analyzed six times on the same day at different time intervals and for interday precision the solutions were analyzed on three different days. Peak area responses of six replicate analyses were calculated in terms of relative standard deviation (RSD).

\section{Ruggedness}

Ruggedness of the method was studied by different analysts analyzing standard solutions containing $8 \mu \mathrm{g} / \mathrm{mL}$ LFNM, Imp A, and Imp B in the optimized conditions in the same laboratory conditions. \%RSD values of peak area responses of six replicate analyses were calculated.

\section{Robustness}

Robustness of the proposed method was tested by slight variation in optimized method conditions. Change in $\pm 5 \mathrm{~nm}$ of detector wavelength, $\pm 5 \mathrm{~mL}$ variation in mobile phase organic and $\mathrm{pH}$ modifier, $\pm 0.1 \mathrm{~mL}$ mobile phase flow rate, and \pm 0.1 factor of $\mathrm{pH}$ was studied. In each of the changed conditions, standard solutions containing $8 \mu \mathrm{g} / \mathrm{mL}$ LFNM, Imp A, and Imp B were analyzed in triplicate. The percentage change was calculated.

\section{Recovery}

The standard addition method was carried out for determining the accuracy of the method. For this, 50\%, 100\%, and $150 \%$ level concentrations were spiked into a known concentration of $1 \mu \mathrm{g} / \mathrm{mL}$. Accuracy was determined by comparing the difference between the spiked value and the actual found value.

\section{Force degradation studies}

\section{Acid hydrolysis}

First $50 \mathrm{mg}$ of drug was mixed with $50 \mathrm{~mL}$ of $0.1 \mathrm{~N} \mathrm{HCl}$ solutions. After incubation for $12 \mathrm{~h}(\mathrm{AH}$ 1) and $24 \mathrm{~h}(\mathrm{AH} 2)$, the sample solution was neutralized and diluted up to standard concentration of $250 \mu \mathrm{g} / \mathrm{mL}$ and was analyzed in the developed method conditions.

\section{Base hydrolysis}

First $50 \mathrm{mg}$ of drug was mixed with $50 \mathrm{~mL}$ of $0.1 \mathrm{~N} \mathrm{NaOH}$ solutions. After incubation for $12 \mathrm{~h}(\mathrm{BH} 1)$ and $24 \mathrm{~h}(\mathrm{BH} 2)$, 
the sample solution was neutralized and diluted up to standard concentration of $250 \mu \mathrm{g} / \mathrm{mL}$ and was analyzed in the developed method conditions.

\section{Oxidative degradation}

First $50 \mathrm{mg}$ of drug was mixed with $50 \mathrm{~mL}$ of $3 \% \mathrm{H}_{2} \mathrm{O}_{2}$ solution. After incubation for $12 \mathrm{~h}$ (OD1) and $24 \mathrm{~h}$ (OD2), the sample solution was neutralized and diluted up to standard concentration of $250 \mu \mathrm{g} / \mathrm{mL}$ and was analyzed in the developed method conditions.

\section{Photolytic degradation}

First $50 \mathrm{mg}$ of drug sample was kept in UV light (254 nm). After incubation for $12 \mathrm{~h}$ (PD 1) and $24 \mathrm{~h}$ (PD2), the sample solution was neutralized and diluted up to standard concentration of 250 $\mu \mathrm{g} / \mathrm{mL}$ and was analyzed in the developed method conditions.

\section{Thermal degradation}

First $50 \mathrm{mg}$ of drug sample was kept in an oven at $60^{\circ} \mathrm{C}$. After incubation for $12 \mathrm{~h}$ (TD 1) and $24 \mathrm{~h}$ (TD 2), the sample solution was neutralized and diluted up to standard concentration of 250 $\mu \mathrm{g} / \mathrm{mL}$ and was analyzed in the developed method conditions.

\section{Formulation analysis}

Formulation sample solution of $250 \mu \mathrm{g} / \mathrm{mL}$ prepared from marketed formulation tablets of LFNM (Lefno ${ }^{\odot}-10 \mathrm{mg}$ ) was analyzed in triplicate in the optimized conditions. The peak area response obtained in the formulation analysis was used to determine the applicability of the developed method for the estimation of LFNM in pharmaceutical formulations.

\section{RESULTS AND DISCUSSION}

The aim of the present work was to develop a simple, accurate reverse phase-HPLC-UV method for the quantification of LFNM and its related impurities $A$ and $B$ in pharmaceutical formulations. A literature survey reveals that no method was reported previously for the separation and qualitative and quantitative analysis of LFNM and its related impurities $A$ and $B$. Hence the attempt made here is novel and has significant importance in simultaneous detection and quantification of LFNM and its related impurities $A$ and $B$.

The mobile phase was confirmed by change in different solvent ratios, expected peak shape, and resolution achieved using the mobile phase composition of acetonitrile, methanol, and $0.1 \mathrm{M}$ sodium perchlorate in the ratio of 40:30:30 (v/v). The $\mathrm{pH}$ of the mobile phase was adjusted to 4.6 using $0.1 \mathrm{M}$ perchloric acid. The mobile phase was pumped at a flow rate of $1.0 \mathrm{~mL} / \mathrm{min}$ in isocratic elution. UV detection was carried out at a wavelength of $246 \mathrm{~nm}$ and separation was achieved on a Thermo Scientific Hypersil ODS C18 column (250 mm×4.6 mm; $5 \mu \mathrm{m}$ id). In the optimized conditions, well retained, resolved, and symmetric peaks are observed in the standard chromatogram containing $10 \mu \mathrm{g} / \mathrm{mL}$ LFNM, imp A, and imp B. The standard chromatogram obtained in the optimized conditions is given in Figure 2. The blank analysis was performed by analyzing the mobile phase and it confirmed that no detection was observed in the blank chromatogram (Figure 3 ). This proved that the method developed was specific and no mobile phase interference was observed in the chromatogram.

Prior to validation of the developed method, repeatability and system suitability were determined at standard solution concentrations of 10,15 , and $20 \mu \mathrm{g} / \mathrm{mL}$. The standard solutions were prepared and were analyzed in the developed method conditions in triplicate. The system suitability conditions like plate count, asymmetric factor, and resolution were determined and found to be within the acceptance limits. The RF, RRF, and relative retention time were also calculated and found to be reproducible. Hence the developed method was found to be reproducible and all the system suitable parameters were within the acceptable limits (Table 1).

A six point linear calibration curve was obtained in the concentration range of $0.5-3.0 \mu \mathrm{g} / \mathrm{mL}$. The linear regression equation was found to be $y=50344 x+2396.2 \quad(R=0.999)$, $y=33020 x-169.16(R=0.999)$, and $y=42853 x+606.76(R=0.999)$ for LFNM, imp A, and imp B, respectively. A very high correlation coefficient value (more than 0.999) was observed for LFNM and both impurities, confirming that the method follows a linear relation accurately within the concentration range studied. The linearity results are given in Table 2 and the calibration curve is shown in Figure 4.

Precision of the developed method was tested by analyzing the standard solution at a concentration of $2.0 \mu \mathrm{g} / \mathrm{mL}$. The

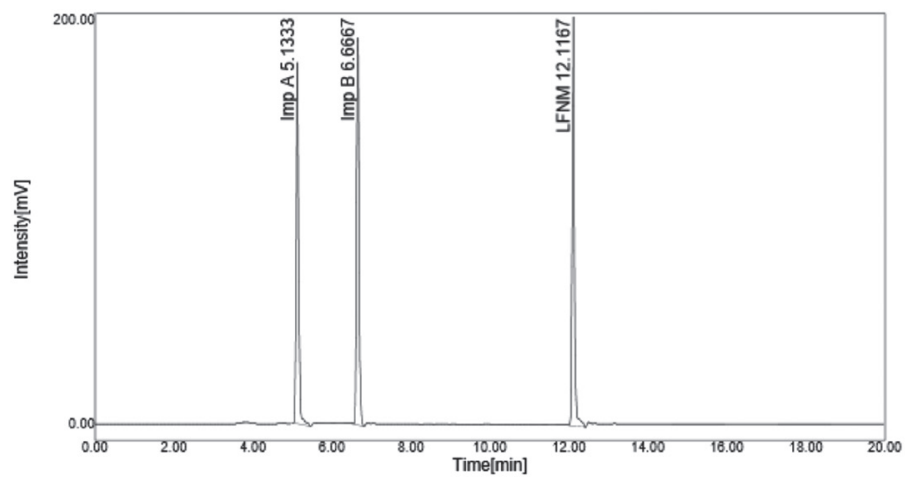

Figure 2. Standard chromatogram of LFNM, Imp A, and Imp and B at a concentration of $10 \mu \mathrm{g} / \mathrm{mL}$

LFNM: Leflunomide

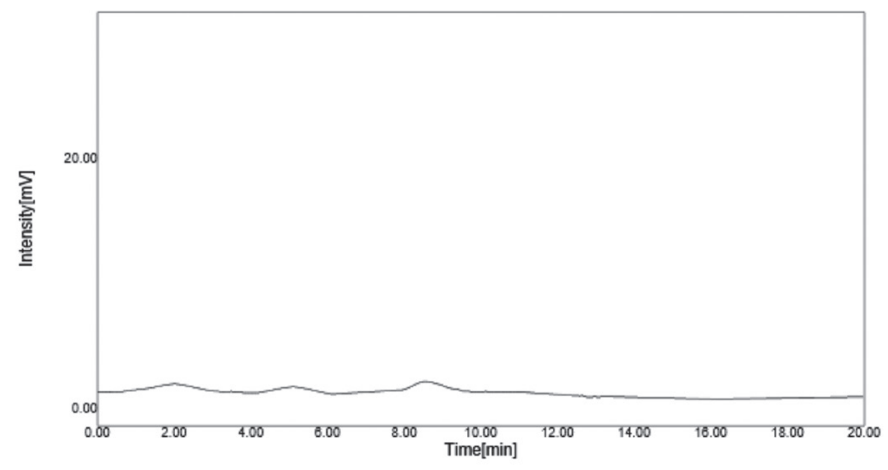

Figure 3. Blank (mobile phase) chromatogram of LFNM, Imp A, and Imp B LFNM: Leflunomide 
solution was analyzed six times on the same day for intraday precision and on three different days for interday precision. The same concentration of solution was prepared and analyzed on three days by three different analysts for ruggedness. The $\%$ RSD was calculated and was found to be $0.383,0.394$, and 0.915 in intraday precision, $0.258,0.236$, and 0.281 in interday precision, and $0.578,0.458$, and 0.491 in the ruggedness study for impurities $A$ and $B$ and LFNM, respectively. The results confirm that the developed method was rugged and precise.

Robustness was tested by analyzing the standard solution in the optimized conditions that were changed deliberately. The percentage change in each changed condition was calculated and was found to be less than 2 (Table 3 ). This confirms that a small change in the analytical conditions did not influence the chromatographic separation and detection of LFNM and its related impurities $A$ and $B$. Hence the method was found to be robust.

Accuracy of the method was determined by spiked recovery studies. For this, 50\%, 100\%, and $150 \%$ concentrations were spiked and analyzed in triplicate into a known concentration of $1 \mu \mathrm{g} / \mathrm{mL}$. The percentage recovery was found to be within the acceptance limit of $98-102 \%$ (Table 4). The \%RSD in each spiked level was calculated and was found to be within the acceptance limit of $<2$. Hence the proposed method was found to be accurate.

The standard drug was exposed to different stress conditions and was analyzed in the optimized conditions and the results were compared with those of an unstressed standard (Figure 5). The percentage degradation was found to be very high in the acid degradation study. In this condition the drug was found to be degraded up to $2.518 \%$ in $12 \mathrm{~h}$ and $10.808 \%$ in $24 \mathrm{~h}$ of stress exposure. The number of degradation products was also found to be high in this condition. Three additional peaks along with both impurities and LFNM were detected in acid condition (Figure 6). In the base degradation study, the drug was found to be degraded up to $2.19 \%$ and $8.619 \%$ after 12 and $24 \mathrm{~h}$ of stress exposure, respectively. One additional peak after $12 \mathrm{~h}$ and two additional peaks after $24 \mathrm{~h}$ (Figure 7 ) of stress exposure along with LFNM and both impurities were detected in base conditions. In oxidative degradation, very low degradation of $1.14 \%$ was observed at $12 \mathrm{~h}$ with no additional degradation compounds, whereas after $24 \mathrm{~h}$ one additional peak was detected and the $\%$ degradation was found to be 5.289 (Figure 8). In the photolytic degradation, $3.13 \%$ degradation with one additional detection was observed at $12 \mathrm{~h}$ and two additional degradation products with \% degradation of 8.887 (Figure 9) were observed. In the thermal degradation, $5.581 \%$ degradation was observed and the

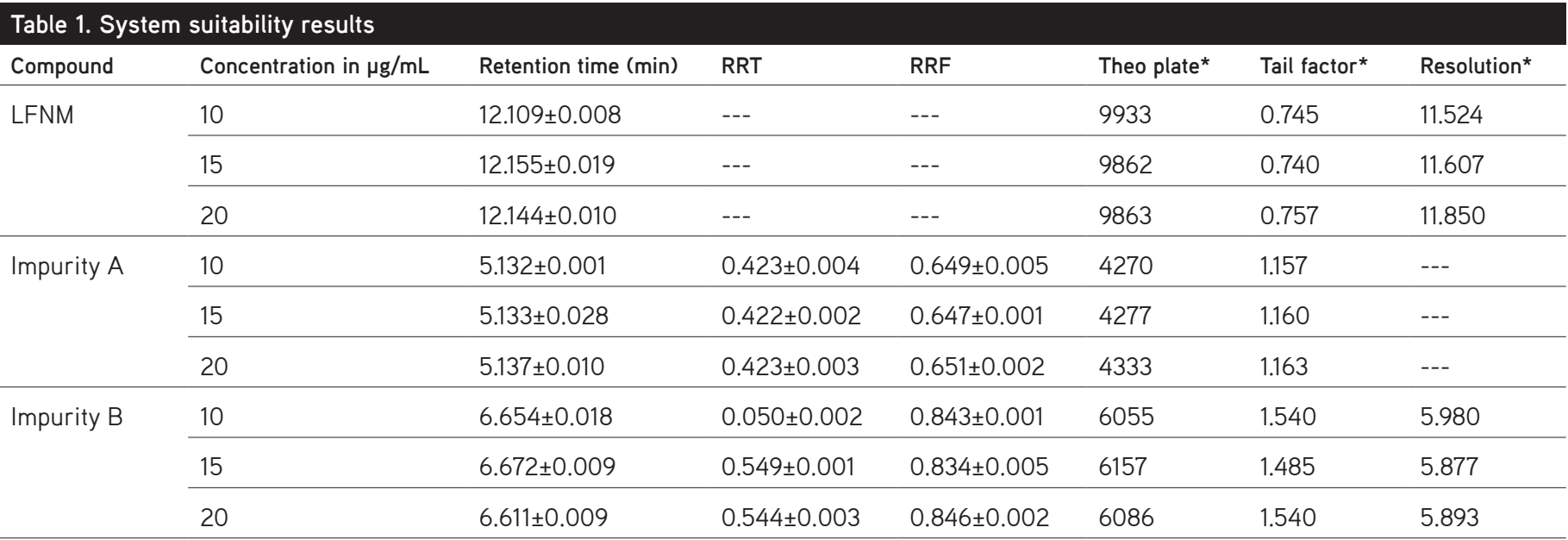

*Values given in table are the average values of three replicate experiments

RRT: Relative retention time, RRF: Relative response factor, LFNM: Leflunomide, min: Minute

Table 2. Linearity results

S. no. Concentration in $\mu \mathrm{g} / \mathrm{mL}$

Peak area observed

\begin{tabular}{lllll}
\cline { 3 - 5 } & & Imp A & Imp B & LFNM \\
\hline 2 & 0.5 & $16243 \pm 198.596$ & $22220 \pm 314.079$ & $26647 \pm 185.176$ \\
\hline 3 & 1 & $32607 \pm 533.094$ & $42538 \pm 227.027$ & $52314 \pm 254.161$ \\
\hline 4 & 2 & $50051 \pm 109.768$ & $65490 \pm 173.463$ & $80610 \pm 109.587$ \\
\hline 5 & 2.5 & $65467 \pm 360.266$ & $86523 \pm 253.997$ & $102530 \pm 1945.648$ \\
\hline 6 & 3 & $82575 \pm 117.091$ & $108259 \pm 1057.730$ & $128587 \pm 2427.108$ \\
\hline
\end{tabular}

*Values given in table are the average \pm standard deviation of three replicate experiments

LFNM: Leflunomide 


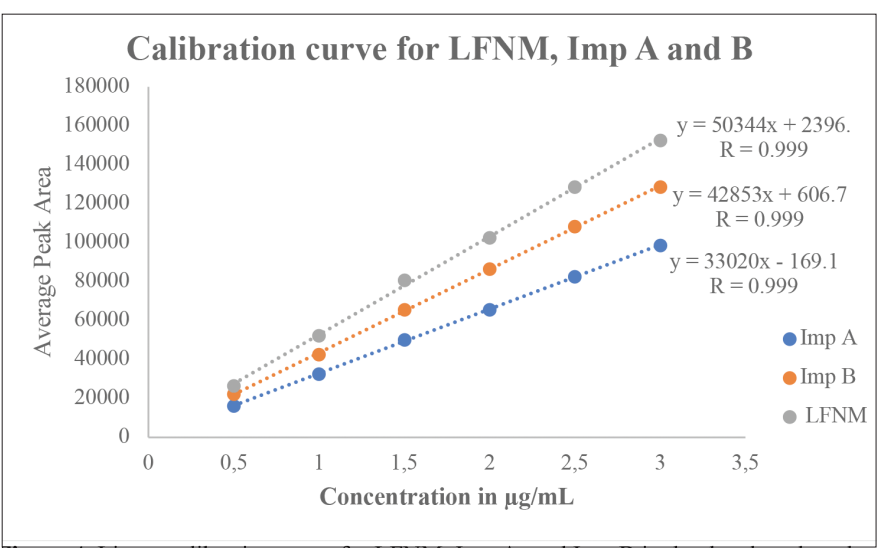

Figure 4. Linear calibration curve for LFNM, Imp A, and $\operatorname{Imp} B$ in the developed method

LFNM: Leflunomide chromatogram shows one additional detection along with LFNM and both impurities (Figure 10). In all degradation conditions, the $\%$ degradation was found to increase with an increase in time. The \% degradation and the formation of a number of degradation products increased with an increase in the stress degradation time from $12 \mathrm{~h}$ to $24 \mathrm{~h}$ in all the conditions studied. The additional detection observed in the stress degradation study along with LFNM and both impurities studied may be unknown impurities formed or the compound degraded due to the stress study. These additional compounds were not observed in the standard unstressed chromatogram. Both the impurities and the degradation products were successfully separated in the optimized conditions and hence the method can separate and quantify the potential impurities in LFNM. The forced degradation results are given in Table 5 .

\section{Table 3. Robustness results}

\begin{tabular}{|c|c|c|c|c|c|c|c|}
\hline \multirow{3}{*}{ S. no. } & \multirow[t]{3}{*}{ Condition } & \multicolumn{6}{|c|}{ Robustness at $2 \mu \mathrm{g} / \mathrm{mL}$} \\
\hline & & \multicolumn{2}{|l|}{$\operatorname{Imp} A$} & \multicolumn{2}{|l|}{ Imp B } & \multicolumn{2}{|l|}{ LFNM } \\
\hline & & Peak area & $\%$ Change & Peak area & $\%$ Change & Peak area & $\%$ Change \\
\hline 2 & MP 1 & 65633 & 0.253 & 85901 & 0.719 & 102981 & 0.439 \\
\hline 3 & MP 2 & 65782 & 0.481 & 85257 & 1.464 & 103102 & 0.557 \\
\hline 5 & WL 2 & 64628 & 1.281 & 86030 & 0.569 & 103782 & 1.221 \\
\hline 6 & $\mathrm{pH} 1$ & 65125 & 0.522 & 86132 & 0.451 & 103075 & 0.531 \\
\hline 7 & $\mathrm{pH} 2$ & 64528 & 1.434 & 85998 & 0.606 & 102903 & 0.363 \\
\hline 8 & FR 1 & 64593 & 1.335 & 85813 & 0.820 & 102745 & 0.209 \\
\hline
\end{tabular}

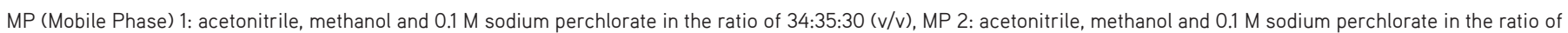
45:25:30 (v/v); WL (Wavelength) 1: $241 \mathrm{~nm}, \mathrm{WL} 2: 251 \mathrm{~nm}$; pH 1: 4.5, pH 2: 4.7; FR (Flow rate) 1: $0.9 \mathrm{~mL} / \mathrm{min}, \mathrm{FR} \mathrm{2:} 1.1 \mathrm{~mL} / \mathrm{min}$.

LFNM: Leflunomide

Table 4. Recovery results

\begin{tabular}{|c|c|c|c|c|c|c|c|}
\hline \multirow[t]{2}{*}{ S. no. } & \multirow[t]{2}{*}{ Compound } & \multirow[t]{2}{*}{ Recovery level } & \multicolumn{4}{|c|}{ Concentration in $\mu \mathrm{g} / \mathrm{mL}$} & \multirow[t]{2}{*}{$\%$ Recovery* } \\
\hline & & & Target & Spiked & Final & Amount recovered* & \\
\hline 1 & \multirow[t]{3}{*}{$\operatorname{Imp} A$} & $50 \%$ & 1 & 0.5 & 1.5 & $1.491 \pm 0.003$ & $99.359 \pm 0.165$ \\
\hline 2 & & $100 \%$ & 1 & 1 & 2 & $1.980 \pm 0.010$ & $99.011 \pm 0.522$ \\
\hline 3 & & $150 \%$ & 1 & 1.5 & 2.5 & $2.464 \pm 0.009$ & $98.548 \pm 0.373$ \\
\hline 6 & Imp B & $150 \%$ & 1 & 1.5 & 2.5 & $2.487 \pm 0.004$ & $99.504 \pm 0.183$ \\
\hline 7 & \multirow[t]{2}{*}{ LFNM } & $50 \%$ & 1 & 0.5 & 1.5 & $1.497 \pm 0.006$ & $99.803 \pm 0.409$ \\
\hline 8 & & $100 \%$ & 1 & 1 & 2 & $1.974 \pm 0.003$ & $98.699 \pm 0.141$ \\
\hline
\end{tabular}

*Values given in table are the average \pm standard deviation for three replicate experiments

LFNM: Leflunomide 


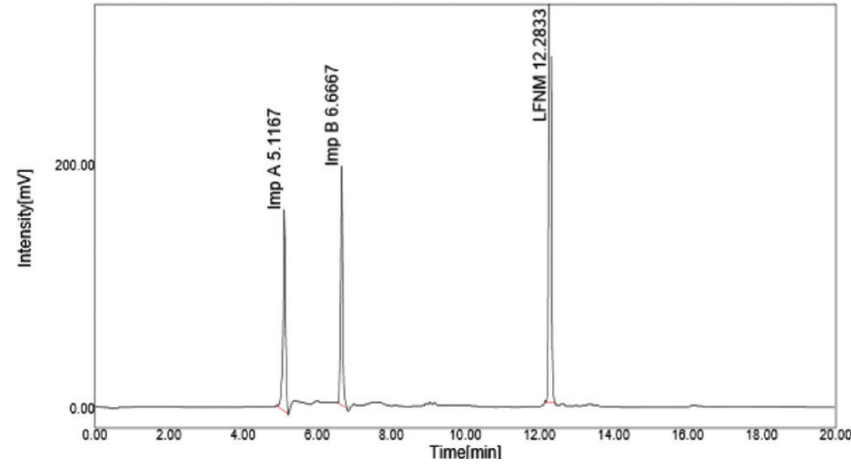

Figure 5. Unstressed (standard) chromatogram of LFNM

LFNM: Leflunomide

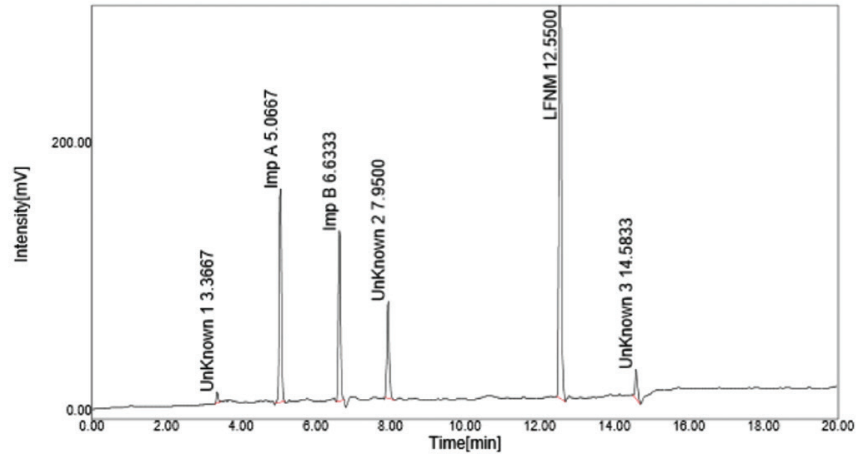

Figure 6. Acid degradation chromatogram of LFNM

LFNM: Leflunomide

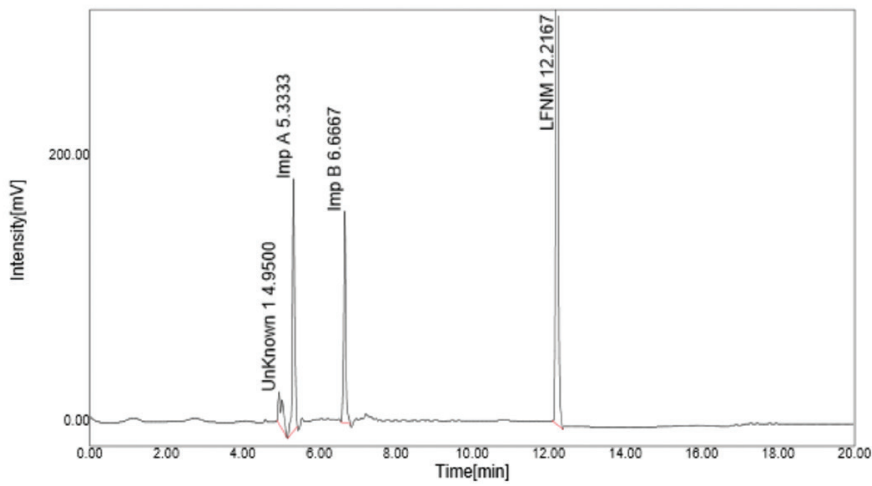

Figure 7. Base degradation chromatogram of LFNM

LFNM: Leflunomide

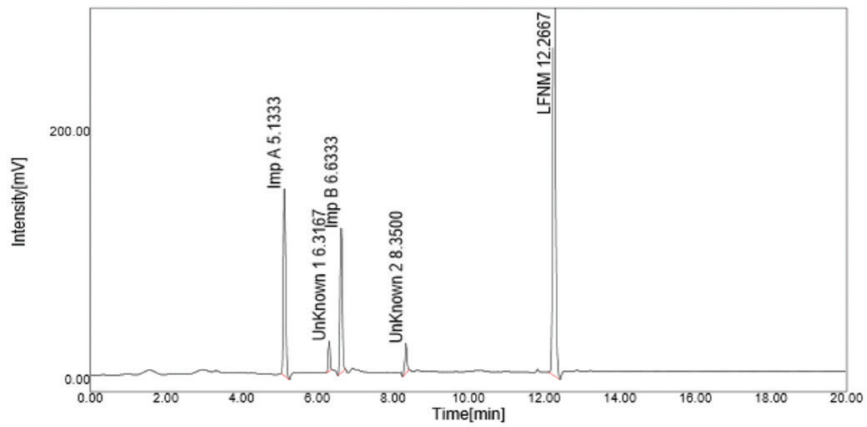

Figure 8. Oxidative degradation chromatogram of LFNM

LFNM: Leflunomide

\section{Table 5. Forced degradation results}

\begin{tabular}{llllll} 
S. no. & Condition & $\begin{array}{l}\text { Number of } \\
\text { additional } \\
\text { peaks } \\
\text { observed }\end{array}$ & Peak area & $\begin{array}{c}\text { \% Amount } \\
\text { remaining }\end{array}$ & $\begin{array}{l}\text { \% Amount } \\
\text { degraded }\end{array}$ \\
\hline 1 & AH 1 & 1 & 12371397 & 97.481 & 2.518 \\
\hline 2 & AH 2 & 3 & 11319358 & 89.191 & 10.808 \\
\hline 3 & BH 1 & 1 & 12412803 & 97.807 & 2.192 \\
\hline 4 & BH 2 & 2 & 11597145 & 91.380 & 8.619 \\
\hline 5 & OD 1 & 0 & 12546917 & 98.864 & 1.136 \\
\hline 6 & OD 2 & 1 & 12019823 & 94.710 & 5.289 \\
\hline 7 & PD 1 & 1 & 12293071 & 96.864 & 3.135 \\
\hline 8 & PD 2 & 2 & 11563280 & 91.113 & 8.887 \\
\hline 9 & TD 1 & 0 & 12481397 & 98.350 & 1.652 \\
\hline 10 & TD 2 & 1 & 11982822 & 94.419 & 5.581 \\
\hline & & & & & \\
\hline
\end{tabular}

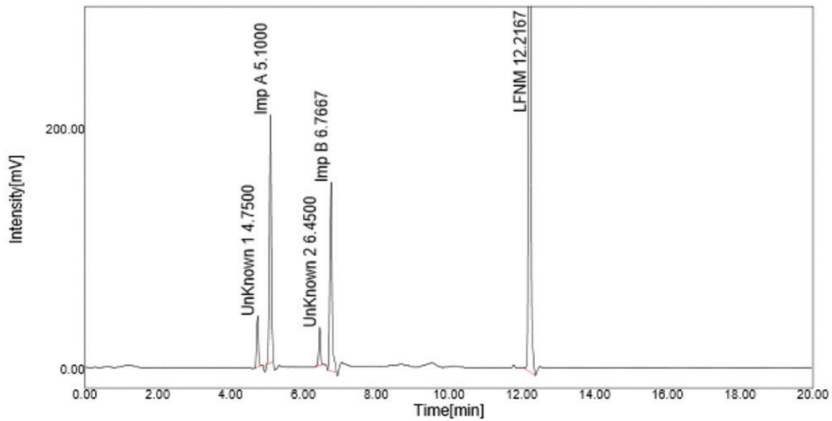

Figure 9. Photolytic degradation chromatogram of LFNM LFNM: Leflunomide

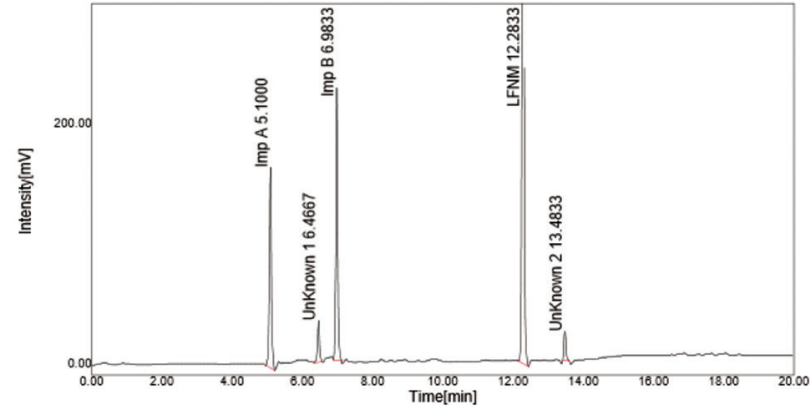

Figure 10. Thermal degradation chromatogram of LFNM

LFNM: Leflunomide

The formulation sample solution of LFNM was analyzed in the developed method conditions in triplicate. The peak area response of LFNM was used for determination of the applicability of the developed method for the analysis of LFNM in pharmaceutical formulations. A standard regression equation was used for the determination of formulation assay and the $\%$ assay was found to be $98.735 \%$. In the formulation chromatogram both the impurities were detected (Figure 11) and other chromatographic impurities and formulation excipients did not interfere with the results. Hence the developed method 


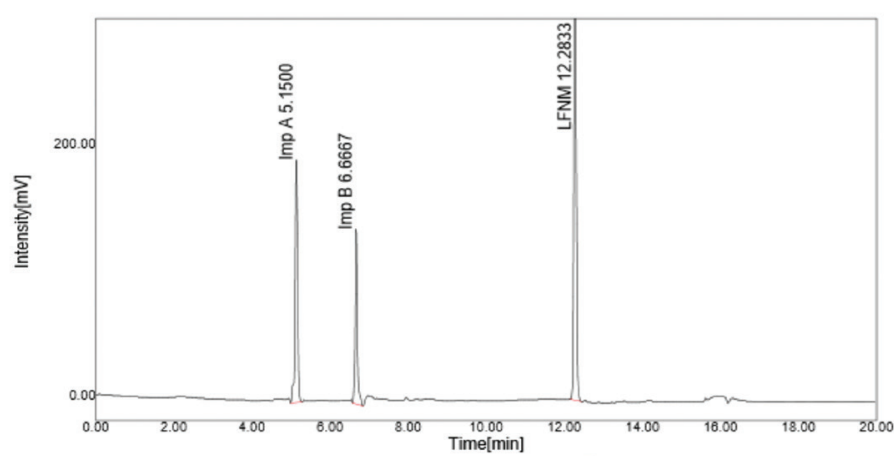

Figure 11. Formulation chromatogram of LFNM (Lefno $\left.{ }^{\odot}-10 \mathrm{mg}\right)$

LFNM: Leflunomide

was found to be suitable for the quantification of LFNM and can separate and analyze impurities $A$ and $B$.

\section{CONCLUSION}

A simple, validated, and fast stability indicating HPLC method is established for quantification of LFNM and its potential USP impurities $A$ and $B$. In the literature no method was found to be established for the simultaneous quantification of LFNM and its potential impurities A and B. Hence the method represents the first report about a stability indicating method for the determination of LFNM in the presence of impurities. The proposed method achieves satisfactory separation of LFNM from impurities and the degradation products, an extended linear range, and rapid analysis time. A high recovery of LFNM in formulation was obtained. The proposed method ensured precise and accurate determination of LFNM in pharmaceutical formulations. The excipients present in the formulation were not interfering in the method. Hence the method is simple, convenient, and suitable for analyzing LFNM in bulk and in pharmaceutical formulations in the presence of its potential impurities $A$ and $B$.

Conflict of Interest: No conflict of interest was declared by the authors.

\section{REFERENCES}

1. Anthony CA. Immunosuppressive drugs: the first 50 years and a glance forward. Immunopharmacology. 2000;47:63-83.

2. Reuben A. Hepatotoxicity of Immunosuppressive Drugs. In: Kaplowitz N, DeLeve LD, eds. Drug-Induced Liver Disease ( ${ }^{\text {rd }}$ ed). New York; Academic Press; 2013:569-591.

3. Li EK, Tam LS, Tomlinson B. Leflunomide in the treatment of rheumatoid arthritis. Clin Ther. 2004;26:447-459.

4. Nash P, Thaci D, Behrens F, Falk F, Kaltwasser JP. Leflunomide improves psoriasis in patients with psoriatic arthritis: an in depth analysis of data from the TOPAS Study. Dermatology. 2006;212:238-249.

5. Sanders S, Harisdangkul V. Leflunomide for the treatment of rheumatoid arthritis and autoimmunity. Am J Med Sci. 2002;323:190-193.
6. Konemann S, Dorr M, Felix SB. The Heart in Rheumatic, Autoimmune and Inflammatory Diseases, Cardiac Immunomodulation, Pathophysiology. Clinical Aspects and Therapeutic Approaches. New York; Academic Press; 2017:681-714.

7. Palled MS, Padmavathi YD, Bhat AR. Development and validation of RP-HPLC method for the estimation of leflunomide in bulk drug and tablets. RJPBCS. 2014;5:659-667.

8. Saini B, Bansal G. Isolation and characterization of a degradation product in leflunomide and a validated selective stability-indicating HPLC-UV method for their quantification. JPA. 2015;5:207-212.

9. Miron DS, Soldattelli C, Schapoval EES. HPLC with diodearray detection for determination of leflunomide in tablets. Chromatographia. 2006;63:283-287.

10. Yeniceli D, Ak D, Tuncel M. Determination of leflunomide in tablets by high performance liquid chromatography. J Pharm Biomed Anal. 2006;40:197-201.

11. Govind JK, Vijay RR, Kapil LD, Atul HB, Hitendra SJ. Validation of a stability-indicating LC method for assay of leflunomide in tablets and for determination of content uniformity. Int $\mathrm{J}$ Chemtech Res. 2011;3:523-530.

12. Prathyusha Naik CN, Chandra Sekhar KB, Muneer S. A novel stability indicating RP-HPLC method development and validation of leflunomide in bulk and its dosage form. Int J Res Pharm Sci. 2016;7:47-51.

13. Srinivas Rao V, Sunanda KK, Narasimha Rao M, Allam Appa Rao, Maheswari IL, Srinubabu G. Development and validation of LC method for the determination of leflunomide in pharmaceutical formulations using an experimental design. Afr J Pure Appl Chem. 2008;2:010-017.

14. Patel SK, Patel KH, Karkhanis VV, Captain AD. Development and validation of analytical method for estimation of leflunomide in bulk and their pharmaceutical dosage form. Austin J Anal Pharm Chem. 2015;2:1046-1056.

15. Govind JK, Vijay RR, Gaurang PP, Hitendra SJ. Development and validation of a stability indicating UPLC assay method for determination of Leflunomide in tablet formulation. Der Chemica Sinica. 2011;2:65-74.

16. Lakshmana Prabu S, Suriya Prakash TNK, Shanmugarathinam A. Development of difference spectrophotometric method for the estimation of leflunomide in tablet dosage form. Chem Ind Chem Eng Q. 2012;18:407-410.

17. Pal NR, Chakraborty M, Debnath R, Gupta BK. Spectrophotometric method for estimation of leflunomide in bulk and tablets. Asian $J$ Chem. 2010;22:1649-1651.

18. Sultana N, Arayne MS, Khan MM, Ali SN. Development of liquid chromatography UV method for simultaneous determination of leflunomide and NSAIDs in API and pharmaceutical formulations: It's application to in vitro interaction studies. Med Chem. 2013;3:262270.

19. Schmidt A, Schwind B, Gillich M, Brune K, Hinz B. Simultaneous determination of Leflunomide and its active metabolite, A77 1726, in human plasma by high performance liquid chromatography. Biomed Chromatogr. 2003;17:276-281.

20. Sola KA, Dedhiya PP, Shah SA. Development and validation of HPTLC method for estimation of leflunomide in its pharmaceutical dosage form. IJDRA. 2017;5:60-67. 
21. Talaat W. Bioanalytical method for the estimation of coadministered esomeprazole, leflunomide and ibuprofen in human plasma and in pharmaceutical dosage forms using micellar liquid chromatography. Biomed Chromatogr. 2017;31. Epub 2016 Nov 15.

22. Sobhani K, Garrett DA, Liu DP, Rainey PM. Rapid and simple highperformance liquid chromatography assay for the leflunomide metabolite teriflunomide (A77 1726), in renal transplant recipients. Am J Clin Pathol. 2010;133:454-457.

23. Chan V, Charles BG, Tett SE. Rapid determination of the active leflunomide metabolite A77 1726 in human plasma by high- performance liquid chromatography. Journal of Chromatography B. 2004;803:331-335.

24. Pawiñski T, Gralak B. HPLC determination of active metabolite of leflunomide in plasma. Chem Anal. 2005;50;785.

25. $\mathrm{ICH}$ Harmonised Tripartite Guideline, Validation of Analytical Procedures. Text and Methodology. ICH Q2(R1). The European Agency for the Evaluation of Medicinal Products (CPMP/ ICH/381/95), 1995. 